\title{
Factors That Affect the Teaching of English Composition at Ordinary Level: Case of Hwange District in Zimbabwe
}

Gasva D.

Senior Lecturer, Department of Teacher Development, Zimbabwe Open University, Hwange, Zimbabwe Email: gasvad@zou.ac.zw

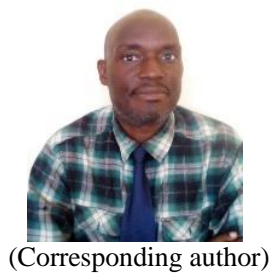

\author{
Article History \\ Received: 18 December 2021 \\ Revised: 16 January 2022 \\ Accepted: 20 January 2022 \\ Published: 23 January 2022
}

\section{How to Cite}

Gasva, D. (2022). Factors That Affect the Teaching of English Composition at Ordinary Level: Case of Hwange District in Zimbabwe. Sumerianz Journal of Education, Linguistics and Literature, Vol. 5, No. 1, pp. 1-9.

\begin{abstract}
This study sought to establish factors that affect the teaching of English composition at Ordinary (O) level in Zimbabwe. The participants $(n=10)$ were O level English teachers from Hwange District in Matabeleland North Province, Zimbabwe. The teachers were selected through purposive sampling. Interviews were used to generate data that were presented in percentages and analysed through content analysis, while being guided by research objectives. The major findings of the study were that the teaching of English composition at $\mathrm{O}$ level is largely affected by teachers'competencies, teaching methods used by the teachers, a language-rich learning environment and teacher motivation and morale, among other factors. Other school related factors such as the amount of time allocated to the teaching of English composition on the school timetable, provision of timely and meaningful feedback to learners on written compositions as well as teachers' attendance of staff development workshops; were also noted to be influential. Accordingly, the researcher concluded that the teaching of O level English composition in the area under study is largely affected by a combination of teacher and other school related factors. It is recommended that for improvement and effectiveness in the teaching of English composition, teachers need to be motivated, boost their teaching competencies, use learner-centred teaching methods and provide a language-rich and conducive learning environment to O level English students.
\end{abstract}

Keywords: Teaching; Learning; English; Language; Composition; School; Performance.

\section{Introduction}

In most parts of the world including Zimbabwe, English is taught as a second language (L2), which is the language that is learnt after acquiring the first or native language (L1) (Carrasquillo, 2004). In the case of this study, English is considered a second language as learners' native or first languages (L1) include Nambiya, Tonga, Dombe, Nyanja and to some extent, Ndebele and Shona. The study was conducted in Hwange District of Matabeleland North Province in Zimbabwe where the cited native languages are spoken. Zimbabwe is a former British colony as a result of its colonial past, and consequently, English Language is the official language which is now required for effective communication both at school, the world of work and in other formal social interactions. The current globalisation and technology revolution calls for proficiency in English language; which underscores the importance effectively teaching English composition (Brown, 2000). As noted by Macaro (2016), there are many types of English composition that are taught at Ordinary (O) level and these include narrative, descriptive, argumentative, situational composition and so on.

O level English teachers in Zimbabwe and, possibly in other countries with similar circumstances, are affected by a number of factors in their quest for effective English literary instruction (Harmer, 2010), and the teaching of $\mathrm{O}$ level English composition is not exception. Possibly because English Language is taught as L2, many aspects of the 
teaching and learning tasks which include composition writing tend to pose some challenges. For Brown (2000) supported by Carrasquillo (2004), English composition is an activity which must be taught and mastered by learners so as to express their ideas effectively. As highlighted by the Zimbabwe Schools Examinations Council ZIMSEC (2011), one of the major concerns of English teachers in Zimbabwe is to develop the skills and knowledge necessary for learners to effectively write good English compositions. For example, most students generally lack originality basing on the given topic as well as lack proper sequence and organised flow of ideas. It is common to find different ideas placed in one paragraph, devoid of developing into sequential ideas that characterise a good composition. More so, most English essays by learners lack a properly defined structure and also lack a good introduction, body and conclusion. ZIMSEC (2011), believes that such learner shortcomings are associated with teacher and school related factors that, directly or indirectly affect the teaching of English composition at O level.

Most English language teachers are of the view that composition writing is the most difficult component of learning the subject, followed by written grammar; an observation also highlighted by ZIMSEC (2011). A good English composition should have correct spelling, punctuation and properly arranged sentences with recommended word division (Brown, 2000). Teachers have the responsibility to instill in a learner's mind, the importance of these aspects, hence learners should be taught to punctuate properly, spell words correctly and improve word division as well as frequently practice composition writing. Motala (2000), states that in order to improve English essay writing techniques, teachers should put great emphasis in the use of figurative language and various errors that crop up in learners' compositions. Important too is the need for English teachers to teach discourse markers; for compositions without them do not flow and tend to 'hang' together (ZIMSEC, 2011). An essay which is devoid of cohesive linguistic devices is usually disjointed, jerky and jarring. For Kanwal and Khurshid (2012), teachers should ensure that compositions written by their students depict a sequential flow of events.

Studies in some Zimbabwean schools revealed that failure to comprehend English essay writing techniques is partly a reason to the high failure rate in English Language (Nziramasanga, 1999). From its findings, the Commission noted that teachers really need English proficiency to be emphasized as it affected other subjects. Harmer (2010), reiterates that writing instruction is a shared responsibility across secondary school disciplines. Teachers must devote significant attention to the teaching of language skills and creating a language-rich envioronment if they expect learners to effectively write English compositions. Thus, language teachers should, therefore focus on exposing learners to a language-rich learning environment, where language skills are frequently taught, practiced and language resources are available.

Teaching composition is a cognitive process involving teachers helping learners to think and create new thoughts. Through composition writing, learners are taught to improve their mental and writing skills because as learners learn to write coherently, they organize their thinking processes (Seliger and Shohamy, 2009). There has been considerable concern that most of the $\mathrm{O}$ level teachers do not effectively assist learners to develop the proficiency for writing good English compositions. Notably, the deteriorating English language performance has been experienced for both internal and external examinations in the Zimbabwean education sector (Nziramasanga, 1999). Learners' ability to achieve communicative proficiency in writing is imperative in the development of English language skills and the writing of good compositions in particular. Thus, O level learners ideally require this skill in order to succeed in their academic aspirations including writing good composition. The researcher was convinced that the reportedly declining performance of most English language learners during public examinations in Zimbabwe is largely a function of learners' poor performance in English composition. This, therefore, necessitated the current study which focused on exploring the factors that affect the teaching of English composition at $\mathrm{O}$ level.

\subsection{Statement of the Problem}

Generally, most Ordinary level learners in Hwange District are not able to express themselves clearly in English which is their second language (L2). This has serious implications as it negatively affects their performance in composition writing. Poor composition writing by learners has ripple effects as it also affects their ultimate performance in their public $\mathrm{O}$ level examinations, yet for them to be considered to have a full certificate at this level, passing English is a requirement. Since English language is being taught as L2, most of the learners are not able to effectively create stories in the process of writing an English composition. The problem at stake is to determine the factors that affect the teaching of O level English composition, using the case of Hwange District in Zimbabwe.

\subsection{Objectives of the Study}

The study was guided by the following objectives:

- To find out the effect of teacher competencies on the teaching of O level English composition.

- To determine the effect of teaching methods on the teaching of O level English composition.

- To assess the effect of a language-rich learning environment on the teaching of $O$ level English composition.

- To establish the effect of teacher motivation and morale on the teaching of O level English composition.

- To examine the effect of other school related factors on the teaching of O level English composition.

\subsection{Significance of the Study}

It is envisaged that the research would mostly be important to the Ministry of Primary and Secondary Education (MoPSE), teachers, learners and other education stakeholders. The MoPSE may be encouraged to motivate teachers by improving their salaries and working conditions since these have been noted to have a bearing on teacher performance and ultimately learner attainment. The same Ministry may also allocate funds for teacher capacity 


\section{Sumerianz, Journal of Education, Linguistics and Literature}

programmes for English teachers. In the same vein, schools, clusters and districts can also consider providing inservice training programmes for English teachers to complement Ministry and also help them cope with curricular changes necessitated by the new school curriculum. Teachers would be urged to upgrade their competencies through in-service programmes; which will enable them to keep abreast with changes relating to the teaching of English composition. Thus, teachers' improved subject knowledge and pedagogic skills will lead to the effective teaching of O level English composition. School authorities may also consider increasing the time allocated to the teaching and learning of English composition at $\mathrm{O}$ level, which may see more lessons being allocated on the school timetable; thereby giving learners enough time for this important learning area. Such efforts and development will no doubt enhance learners' performance in English composition writing as well as their ultimate achievement in the English Language subject at $\mathrm{O}$ level.

\section{Review of Related Literature}

The areas covered by the review of related literature are the effect of teacher competencies, teaching methods, a language-rich learning environment and other school related factors on the teaching of English composition at $\mathrm{O}$ level.

\subsection{Effect of Teacher Competencies}

Teacher competence in the context of this study is a function of a number of things including teacher qualifications, experience and general ability to teach $\mathrm{O}$ level English composition. The use of English as a medium of instruction has rendered the teaching and learning of English in general, and composition in particular, to be difficult in the area under study as English is a second language (L2). Research has proved that more qualified and experienced English teachers are more likely to teach and produce better learner results than less qualified and experienced teachers (Seliger and Shohamy, 2009). This implies that such teachers are more competent to teach language components including English composition. In the case of most Zimbabwean schools, it is rare to find an unqualified teacher offering English at $\mathrm{O}$ level though their teaching experience may vary from school to school (ZIMSEC, 2011). It is however not a deniable fact that for some reason, some of the secondary school teachers may not possess adequate proficiency in English for the effective teaching of composition to take place. As a result of this, such teachers use limited English, often use it incorrectly or resort to their native language to explain unclear L2 composition aspects.

Highlighting the variations among English language teachers, Harmer (2010) notes that complexity generally arises in language teaching with regard to their qualifications. The teacher may speak the language natively may have studied it on second language basis. It is therefore obvious that some teachers may deliberately disregard teaching certain basic L2 skills they find problematic themselves; which would have detrimental effects on the teaching of English composition. It is therefore essential that the teacher be equipped both in content and pedagogic skills in order to effectively handle the teaching of an English composition lesson in which the learner is the benefactor. The major role of the teacher in an English composition lesson, among others, is to organize the learning context by availing necessary elements of and guidelines for the intended task (Carrasquillo, 2004).

The English language teacher must be a treasure house of knowledge and information and yet giving minimum possible help to the learners- only that which helps the learners to be creative and story composers (Cohen, 2008). In addition to motivating the learners to write good compositions, the teacher should also be a good guide giving that amount of guidance which is needed by learners. He or she should be proficient when questioning learners with regards composition tasks. Furthermore, he or she should be capable enough to plan and devise problems for investigation by the learners (Brown, 2000). Thus, all the above qualities should be inherent in the O level English teacher; which would no doubt guarantee his or her capability to effectively and successfully teach composition writing to the learners.

\subsection{Effect of Teaching Methods}

Teaching methods refer to strategies used to help students learn the desired course content in order to attain set objectives and be able to develop in line with the broad goal of the lesson (Brown, 2000). The same source says that the nature of teaching methods or strategies adopted by the teacher have a bearing on learners' educational achievement and are largely based on the constructivist philosophy. This is a view of teaching and learning based on the belief that knowledge is not a thing that can simply be given to learners by the teacher in front of the classroom. Rather, knowledge is constructed by learners through an active mental process of development where the learners are the builders and creators of meaning and knowledge (Piaget, 1977 cited in Harmer (2010)). This implies that in teaching composition, teachers should predominantly mostly use the constructivist approach. There should be a shift from the traditional teaching approach to the more learner-centred approaches since learner participation and enthusiasm depend mostly on the teaching method employed by the teacher.

Weiner (1980) cited in Carrasquillo (2004) avers that the nature of teaching methods used is critical in determining the success or otherwise of any lesson. The methods used to teach composition generally entail shared teaching and learning which involves exchanging of letters, sharing journals, cooperative learning, making a class magazine, role play, group work and so on. Constructivist English composition teachers encourage learners to constantly assess how the creative activity is helping the learners gain understanding, by questioning themselves in their strategies. For educational psychologists, students in the constructivist classroom ideally become expert learners as they learn how to learn; and learning, therefore, occurs by an active construction of meaning (Brown, 
2000). The English composition learner is supposed to benefit from the educator's teaching methods and he or she should be involved more than the teachers which fulfils the pedagogical dictates of the learner-centred approach.

Previous studies have shown that writing is something that teachers expect learners to do in class without giving a prior thought to the meaning of the finished product (Harmer, 2010). There are, however weaknesses associated with the product approach to composition writing. Kanwal and Khurshid (2012), assert that this approach pays little attention to audience and the writing purpose since learners and teachers are more concerned with the importance of syntax, grammar and the mechanics of writing. Researchers in the field of English composition writing note that there is more to writing than the product. Brown (2000), believes that composition writing is a process which involves several noticeable steps or stages, with the strategies challenging learners to think creatively through activity and using logical thinking; all of which are facets of pedagogy.

\subsection{Effect of a Language-Rich Learning Environment}

When learners are working on the task of composition writing in English as a second language (L2), they are engaging actively with the new language and culture (Macaro, 2016). The same source notes that the more the learner practices this, the more they become acquainted with the patterns of the English language including vocabulary, syntax and cultural assumptions of the native speakers of the language. By so doing, they learn a great deal about how to write a good composition in L2. So in learning English composition writing, reading materials are of paramount importance to the learner. For a learner to write effective compositions he or she should have read a lot of materials in order to improve language proficiency, as this helps in tackling any type of English (Harmer, 2010). Provision of reading materials that aid language skills development in general and also composition wiring in particular is the responsibility of the teacher and school with of course, the support of parents and other education stakeholders.

In support of the above, Kanwal and Khurshid (2012) identified the provision of a language-rich environment as a producer of positive outcomes in English composition writing achievement. The following have been found to enhance composition writing proficiency: films and drama which are audio visual simulation using letter boxes to increase learner-teacher communication, reading of novels, newspapers, magazines, pamphlets and so on. Charts, diagrams, maps and pictures can also be used to illustrate abstract concepts, which will assist learners to better conceptualise English language; thereby further enhancing composition writing skills. Generally, reading and writing are, therefore, learning activities that can support, complement and contribute to improved English composition writing (Neeta and Klu, 2013). Accordingly, schools that expose O level English learners to a language-rich environment are better positioned to expect higher learner performance in English Language in general and composition writing in particular.

\subsection{Effect of Teacher Motivation and Morale}

The responsibility teachers have in the classroom and their level of motivation and morale has become intricately linked to student performance and attainment (Yurashie, 2011). A study conducted in Kentucky District schools in North Carolina by Kelley et al. (2012) suggests that teachers associate a variety of positive and negative circumstances with their classroom perfomance. Positive circumstances mentioned included reasonable high salaries, payment of bonus, incentives and favaourable leave conditions. The meeting of teacher expectations by school authorities was also noted to be an important predictor of school success, as this was related to the presence of enabling working conditions as well as teacher satisfaction. The findings of the same study also suggest that school curriculum designers need to focus on setting realistic teaching and learning goals as well as providing enabling conditions for learner success and general school effectiveness.

In the same vein, the USC Rossier School of Education (2011) notes that teacher motivation plays an important role in the school because it enhances teacher performance. This means that where teachers are motivated, the teaching and learning goals can be achieved in an efficient way, and where teachers are not motivated both teacher and learner performance are compromised. Thus, the behaviour and participation level of teachers in the classroom can be changed through motivating them and boosting their morale. Research findings by Donkor and Niamatu-Lai (2017) show that inadequate motivational packages for teachers in many developing countries particularly in Africa has negative effects on the performance of the teachers. The same source notes that teachers are generally motivated by reasonably good salaries, fringe benefits and job security, among other motivators.

\subsection{Effect of Other School Related Factors}

There are quite a number of other general school related factors that may impact on the teaching and learning of English composition at $\mathrm{O}$ level. For example, the time that is allocated for composition lessons on the school timetable is an important factor. In Zimbabwe, the revised Ministry of Primary and Secondary Education (MoPSE) Circular P36 on written work provides that English composition at O level be taught once every fortnight (MoPSE, 2015). This tends to limit learners from taking enough composition writing practice as learners are expected to do a number of things that require a lot of time, particularly so with English composition considering that English is a second language (L2) to most learners in the country. For example, learners identify what and why they are writing; gather material through observing, brainstorming, making notes or lists, talking to others and reading. They also plan how to go about the task of composing and how to organize the composition material. They then write and read the draft, revise and proof read for errors which all call for enough time in order to cover the tasks involved (Makoni, 1993). When planning any curriculum and its subject components, it is important to give enough time for learners to explore a topic thoroughly, more so with composition writing that calls for creativity and skills in writing 
organisation (Harmer, 2010). Makoni (1993), further notes due to limited time, English teachers usually do not have enough time to integrate the four language skills which are speaking, reading, listening and writing when teaching composition. Teachers also tend to rush learners in assigning them to write compositions, yet composition requires lots of time as it involves creative thinking and writing.

Educational feedback has also been shown to be necessary in improving learner perfomance and achievement (Harmer, 2010). The same source says that teachers should provide learners with constructive feedback on how they would have performed in a learning task. Such feedback should be provided timely to help the learners understand how they can better perform in their learning task. Another important school related factor is teachers' staff development, which Showers (2018) believes is indispensable in influencing the teaching of any school learning area. Staff development or inservice-training for educators is considered instrumental in promoting educational effectiveness as the reputation of any school is, in essence, determined by its ability to produce good pupil results (Steyn, 2010). Actually, good performance in composition writing is due to the role played by effective teachers. Thus, the effectiveness of any educational system largely depends on the quality of teachers, hence, the need for their professional development (Steyn, 2010). School staff development is about improving the efficiency and quality of teaching and should, therefore, focus on improving the ability of teachers to undertake specified roles in relation to the delivery of the curriculum (Boyle and Boyle, 2018). In the context of this study, this includes the teaching of $\mathrm{O}$ level composition as it is part of English Language lessons.

\section{Research Methodology}

Research methodology entails the specific procedures or methods used to identify, select, process, analyse and report research data (Creswell, 2014).

\subsection{Research Approach and Design}

The researcher anticipated the type of data needed to respond to the research question, hence, chose to utilise the qualitative approach. For Best and Khan (2013), qualitative research is concerned with non-statistical methods of inquiry and analysis of data that is collected through techniques like interviews, observations, videotapes and case studies. Qualitative research usually uses a case study design and other designs that are consistent with the generation and analysis of qualitative findings (Dey, 2013). The current study utilised the case study design which focuses on understanding the social dynamics present within single cases (Gray, 2019). For purposes of feasibility, the case of Hwange district in Matabeleland North province of Zimbabwe was utilised. The researcher considered the case study to be appropriate since it provided a detailed understanding of the views voiced by teachers in their specific situation (Silverman, 2011; Yin, 2013). Thus, the appropriateness of both the research approach and design used in the current study helped to discover the factors that affect the teaching of English composition at $\mathrm{O}$ level in the area under study.

\subsection{Population and Sample}

The concept of population in qualitative research concerns the target group of individuals with relatively related characteristics from which a sample can be drawn (Leedy and Omrod, 2012; Silverman, 2011). The population of this study was comprised of $\mathrm{O}$ level English teachers in the area under study. As it is often not feasible to study the entire population, the use of a sample for the purpose of making the research problem more researchable was considered (Cohen and Manion, 2007). Since in a qualitative study, sample size is usually not predetermined, the researcher was flexible in this regard and, therefore, utlised the concept of 'data saturation', hence allowed for the determination of the actual sample as the study progressed (Frankel and Wallen, 2006; Small, 2009). Ultimately, a sample of $10 \mathrm{O}$ level English teachers sampled through purposive sampling, was utilised to accomplish the study. This group of participants (teachers) was considered appropriate for the study as it had practical experience in the teaching of English composition at $\mathrm{O}$ level; hence was capable of providing first-hand and reliable data regarding the research problem.

\subsection{Research Instrumentation}

Borg and Gall (2012), assert that research instruments are the tools that allow one to systematically collect data. This study utilised face-to-face interviews; which generally involved the interviewer coordinating the process of the conversation while asking questions while the teachers, who were interviewees, responded to those questions (Cohen and Manion, 2007). The use of interviews involved the recording of information through both text and audios, with audios later on being consolidated into transcribed text data. Interviews were appropriate largely because the information required from the teachers involved explanations and the interviewer was also able to probe for more information on specific issues of the study (Pawlas, 2005). Interviews also helped to build trust and rapport between the interviewer and the teachers which enabled the generation of reliable and trustworthy data (Best and Khan, 2013; Creswell, 2014).

\subsection{Data Generation, Presentation and Analysis Methods}

Burns and Grove (2013) supported by Crotty (2018) aver that the generation and analysis of qualitative data is most appropriately done with the guidance of research objectives. In the current study, data generation was therefore, based on the objectives of the study with the gathered data being presented in percentages. In harmony with qualitative case inquiries, content analysis was utilised in analysing the findings (Weiss, 2019); while making 
reference to related literature where appropriate. This enabled the researcher to make known some of the factors that affect the teaching of English composition at $\mathrm{O}$ level in the area under study.

\section{Presentation and Discussion of Results}

The findings of this study focused on factors that affect the teaching of English composition at O level, using the case of Hwange District in Matabeleland North Province, Zimbabwe.

\subsection{Effect of Teacher Competence on the Teaching of $O$ Level English Composition}

Teachers' professional qualifications and experience were considered of importance in this study because of their possible role in determining teachers' competencies including level of knowledge and pedagogical expertise. From the sample of 10 teachers, the majority 7 (70\%) had a Diploma in Education, while another $3(30 \%)$ had a teaching degree. This suggests that all participants in this study had appropriate professional qualifications to teach English Language, with some having adavanced professionally up to attaining a degree. This scenario provided important insights into how this impacted on the teaching of $\mathrm{O}$ level composition in the area under study; for the teachers were well positioned to offer effective composition lessons. Previouas research reveals that professional qualifications and training of teachers are essential aspects in good mastery of subject content and the acquisition of skills that are appropriate for teaching; which therefore covers the teaching of composition (Cole, 2000).

About 7 (70\%) of the teachers had teaching experience of 6-10 years while another $3(30 \%)$ had teaching experience ranging from 1-5 years. This implies that the majority of teachers had enough experience in teaching English language (more than five years). Thus, with such high teaching experience, most of the teachers had sufficient know-how in handling the teaching of English composition at O level since a long period of teaching a particular subject or content area is believed to enable one to have high content and pedagogical mastery (Donald, 2007). In that regard, the researcher observed that most if not all the teachers in the study were able to fuse their knowledge with their teaching experience in order to produce desirable learning outcomes in English composition writing.

\subsection{Effect of Teaching Methods on the Teaching of O Level English Composition}

More than half of the teachers, that is $6(60 \%)$, indicated that they normally use the lecture method when teaching English composition to O level students. On the same aspect, 3 (30\%) of them said that they use the guided approach where the teacher provides learners with a framework to use in developing the composition. Only 1 (10\%) indicated that she uses the group work and discussion method which involves learners working on a composition topic as a group then coming up with ideas which each student in the group uses to produce a composition. It is unfortunate to note that most teachers used teacher centred methods which pose some challenges because communicative language methodology advocate for learner-centred methods when teaching learning tasks such as composition as the learner is an active constructor of knowledge (Kojic-Sabo and Lightbown, 1999). Learners who were made to work in collaboration with others before writing individual compositions tended to produce good compositions as this promoted cooperative learning which is quite appropriate for handling composition teaching and learning. Thus, in the current study, the nature of teaching methods used was noted to be important in determining the success of O level English composition lessons (Weiner, 1980 cited in Carrasquillo (2004)).

\subsection{Effect of a Language-Rich Learning Environment on the Teaching of O Level English Composition}

A language-rich learning environment is considered by educational psychologits as an important prerequisite in the effective teaching and learning of language subjects, including the teaching of composition (Donald, 2007). In the present study, almost all teachers 9 (90\%) indicated that they generally use both English (L2) and vernacular (L1) such as Nambiya or Tonga when teaching English composition. The teachers defended their action by arguing that they use both L1 and L2 in teaching O level English composition as quite a number of learners do not understand composition writing guidelines and instructions if given only in L2. Only 1 (10\%) said he uses English only, which he however said was quite a challenge to most learners but resorted to the approach so as to create an English language-rich learning environment that would inspire learners to use English effectively in accomplishing their comprosition tasks. Thus, despite the fact that English is the main medium of instruction in Zimbabwean secondary schools, particularly so for English lessons, it is unfortunate to note that it is not solely used in the teaching of English composition at O level. In line with Makoni (1993) previous studies, these findings possibly explain why most $\mathrm{O}$ level learners have challenges in expressing themselves when it comes to English composition writing.

It is also considered that a language-rich learning environment is realised when language teachers know the importance of and how to relate the teaching of grammar to composition (Brown, 2000). In this study, the majority of teachers, that is $7(70 \%)$ said they teach grammar in isolation to composition writing while only $3(30 \%)$ said they do not separate the two concepts. As further noted by Brown (2000), there is a problem with what the majority of English teachers are doing because it is a principle of language pedagogy that grammar for composition should be taught with composition writing in mind, and not in isolation. In the same vein, Cohen (2008) avers that grammar and composition are two concepts that are closely related from a linguistic perspective, hence should not be separated when teaching. Thus, if Englsih $\mathrm{O}$ level teachers relate the teaching of grammar to composition writing, there would be a huge reduction in the grammatical errors noted in learners' compositions; which enhances the quality of compositions learners produce. 


\subsection{Effect of Teacher Motivation and Morale on the Teaching of $O$ Level English Composition}

The study also revealed that quite a large number of teachers, that is, $8(80 \%)$ were not motivated to work due to a number of factors particularly poor salaries and working conditions. On the same issue, only $2(20 \%)$ of the teachers said that they were motivated simply because they liked the teaching profession, regardless of its inferior recognition in society. Thus, low motivation and morale negatively affected the performance of teachers in the area under study with regards the teaching of $\mathrm{O}$ level English composition. This finding was noted to be in agreement with the USC Rossier School of Education (2011) which holds that work motivation has a significant positive effect on teacher performance. The reviewed literature also shows that reasonably good salaries, fringe benefits and job security are often the most important motivators to teachers (Donkor and Niamatu-Lai, 2017). Thus, motivated O level English teachers are most likely to facilitate effective composition teaching and learning, and the opposite is true for demotivated teachers.

\subsection{Effect of Other School Related Factors on the Teaching of $O$ Level English Composition}

There are other school related factors which also have a bearing on the teaching of English composition at $\mathrm{O}$ level. For example, the majority of teachers $7(70 \%)$ indicated that the time allocated for English composition lessons was not adequate to fully cover the aspects which make learners to be capable of writing good compositions. These participants revealed that English composition lessons are done once every forty-night though the lessons are often double lessons. The time frame for composition lessons is very limited which consequently disadvantages learners as compositions are sometimes written as homework, thereby compromising the quality of the written work as it is done without teachers' guidance. Thus, adequate time is a key prerequisite for the effective teaching and learning of English comsposition at O level. This is consistent with Harmer (2010) who advises that when planning any curriculum, it is important to provide enough time for learners to explore a topic thoroughly; which is particularly so for composition writing that calls for creativity and skills in writing organisation.

When asked about provision of feedback to learners, such as discussing learners' composition after marking as well as providing meaningful comments for a marked composition, $8(80 \%)$ of the teachers said they always do which they also claimed to do timeously. About $2(20 \%)$ of the participants said they rarely provide feedback especially because of the pressure of work brought about by the updated Zimbabwean school curriculum. However, these teachers indicated that though they did not provide timeous feedback, they eventually allocated marks to learners' compositions. This scenario shows that not all O level English teachers provide meaningful and timeous feedback to learners; yet it is important in enhancing the exercise of doing corrections as well as improvement in learners' performance in the composition task. Thus, teachers should provide learners with timeous and constructive feedback in order to enhance perfornance in their learning task (Brown, 2000). In the case of the current study, such feedback would enhance O level English learners'performance in composition writing.

Data also shows that most English teachers 7(70\%) never attended staff development wokshops for their subject area. On the same issue, 2(20\%) indicated that they attended just one workshop while only 1 (10\%) teacher had attended more than two cluster inservice worshops in English. Such a scenario is not healthy considering that most of the teachers had not attended a single staff development workshop, yet they are important in assisting teachers to improve their subject content knowledge and pedagogic skills. Consequently, this negatively affects English teachers' performance with regards the teaching of composition; which is further detrimental to learners' achievement in English Language as composition is a key aspect of the subject's examination. This is in harmony with Showers (2018) who avers that staff development is quite instrumental in educational institutions' effectiveness as the reputation of any school is determined by its ability to produce good learner results.

\section{Conclusions of the Study}

Based on the findings, the researcher came up with the conclusion that the teaching of Ordinary level English composition in the area under study is largely affected by a combination of teacher and other school related factors. The major factors noted were teacher competencies, teaching methods used by teachers, a language-rich learning environment, teacher motivation and morale. This scenario could also apply to other schools with similar conditions and circumstances in Zimbabwe and other countries.

\section{Recommendations for the Future}

Based on the above findings and conclusion, researcher recommends that;

- O level English Language teachers should continue upgrading their knowledge and teaching skills which they can do through undertaking higher level professional programmes that are related to their subject area. This will improve their pedagogic skills which will cascade to making them effective composition teachers.

- In order to improve O level learners' English composition writing skills, teachers need to apply the reading -modelling and the process-based approaches. These are capanle of enhancing learners' creative and communicative competence which is handy in composition writing.

- Learner-centred teaching methods such as group discussions, role plays and cooperative learning methods should be used rather than teacher-centred methods like the lecture method in teaching O level English composition. Learner-centred methods allow for learner creativity and interactivity which aid learners to share and build their own ideas thereby enabling them to eventually come up with effective compositions. 


\section{Sumerianz Journal of Education, Linguistics and Literature}

- Schools should revisit the time allocated to the teaching of O level composition on the timetable. Even though its ofetn a double lesson, having the teaching of composition once every forty night as in the current situation is undesirable; since it doesn't give both the teachers and learners enough composition teaching time and writing practice.

- The Ministry of Primary and Secondary Education (MoPSE) and School Development Committees (SDCs) should come up with interventions meant to motivate $\mathrm{O}$ level English teachers as well as boost their morale.

- English heads of departments (HODs) and the school management should monitor and enforce that English teachers provide timely and meaningful feedback to learners on written compositions. This will enable the learners to attend to comments and corrections while their minds are still fresh in relation to the written composition.

- O level English teachers should take it upon themselves to make sure that they attend to as many staff development workshops as possible on English Language teaching in general and the teaching of composition in particular.

- Schools should come up with a language policy that encourages learners to use English Language during subject lessons taught in English. Learners should also be encouraged to speak in English within the school premises which will no doubt improve their linguistic proficiency, thereby aiding them to write good compositions.

\section{References}

Best, J. W. and Khan, V. J. (2013). Research in education. 7th edn: Allyn and Bacon: London.

Borg, W. R. and Gall, M. D. (2012). Educational research: An introduction. Longman: London.

Boyle, B. and Boyle, T. (2018). A longitudinal study of teacher change: What makes professional development effective? Australian Journal of Teacher Education, 7(3): 79-103.

Brown, D. (2000). Principles of language learning and teaching. Longman: New York.

Burns, M. and Grove, S. K. (2013). Understanding qualitative research. Philadelphia: W.B. Saunders.

Carrasquillo, A. L. (2004). Teaching english as a second language: A resource guide. Garland Publishing: New York.

Cohen (2008). Strategies in learning and using a second language. Longman: Essex.

Cohen and Manion, L. (2007). Research methods in education. Milton Park: Routledge.

Cole, G. A. (2000). Management: Theory and practice. Lens Educational Aldine: London.

Creswell, J. W. (2014). Research design: Qualitative, quantitative and mixed methods approaches. 2nd edn: CA: Sage: Thousand Oaks.

Crotty, M. (2018). The foundations of social research: Meaning and perspective in the research process. Sage: Boston CA.

Dey, I. (2013). Qualitative research methodology and design. Routledge: New York.

Donald, J. G. (2007). Improving the environment of learning: Academic leaders talk about what works. Jossey-Bass: California.

Donkor, A. K. and Niamatu-Lai, A. (2017). The effects of motivation on teacher performance in the kaladan circuit of education in the tamale metropolis. International Journal of Education and Evaluation, 3(9): 55-73.

Frankel, J. R. and Wallen, N. E. (2006). How to design and evaluate research in education. McGraw Hill: New York.

Gray, D. E. (2019). Doing research in the real world. 2nd edn: Sage: Los Angeles.

Harmer, J. (2010). How to teach english as a foreign language Teaching and Research Press: New York.

Kanwal, W. and Khurshid, F. (2012). Students' difficulties in learning english language. Language in India, 12(2): 97-115.

Kelley, C., Heneman, H. and Milanowski, A. (2012). Teacher motivation and school-based performance. Educational Administration Quarterly, 38(3): 372-401.

Kojic-Sabo, I. and Lightbown, P. M. (1999). Students' approaches to vocabulary learning and their relationship to success. Modern Language Journal, 8(3): 176-92.

Leedy, P. D. and Omrod, J. E. (2012). Practical research: Planning and design. Pearson: New York.

Macaro, E. (2016). Learning strategies in foreign and second language classrooms. Continuum: London.

Makoni, S. B. (1993). Is Zimbabwean english a type of new english? African Study Monographs, 14(2): 97-107.

MoPSE (2015). Curriculum framework for primary and secondary education. Ministry of Primary and Secondary Education: Harare.

Motala, S., 2000. "Education transformation and quality: The South African experience." In Paper presented at the Annual Meeting of the Comparative and International Education Society, San Antonio, Texas.

Neeta, N. C. and Klu, E. (2013). Teachers' professional knowledge competence and second language education in South Africa. International Journal of Educational Sciences, 5(3): 255-62.

Nziramasanga, C. T. (1999). Report of the presidential commission of inquiry into education and training. Harare, Unpublished.

Pawlas, G. E. (2005). The structured interview: Three dozen questions to ask prospective teachers. Nassp Bulletin, 79(567): 62-75.

Seliger, H. W. and Shohamy, E. (2009). Second language teaching methods. Oxford University Press: Oxford.

Showers, J. (2018). Staff development in the 21st Century. The Falmer: Boston.

Silverman, D. (2011). Doing qualitative research. 3rd Edition edn: Sage: Los Angeles. 
Small, M. L. (2009). The logic of case selection in field-based research. Sage: Beverly Hills.

Steyn, G. M. (2010). Educators' perceptions of continuing professional development for teachers in South Africa. African Education Review, 7(2): 156-79.

USC Rossier School of Education (2011). Factors that affect student academic success. University of Southern Calif Press: Los Angeles.

Weiss, R. S. (2019). The art and method of qualitative studies. N.Y. Free Press: New York.

Yin, R. K. (2013). Case study research: Design and methods, applied social research methods series. 3rd edn: Sage: Thousand Oaks.

Yurashie, W. (2011). Personal management: Applications in the service sector. Press Russian Federation: Saint Petersburg.

ZIMSEC (2011). Examinations report. Zimbabwe schools examinations council-ministry of primary and secondary education. MoPSE: Harare. 